\title{
Quantification of the Impact on the Environment of Romanian National Airlines
}

\author{
CASANDRA VENERA PIETREANU*, SORIN EUGEN ZAHARIA, CORNEL DINU \\ University Politehnica Bucharest, Faculty of Aerospace Engineering, 1-7 Polizu Str., 011061, Bucharest, Romania
}

\begin{abstract}
Air quality is submitted to national and international standards and regulations, thus air traffic growth's implications on the environment can be analyzed only in compliance with such norms. While achieving the requirements of environmental protection reflected by legal frameworks, airlines have to establish their own responsibility policy based on emission reduction options, which can be approached by market strategies and technological developments. In this context, the paper aims at analyzing this long-term challenge for the Romanian aeronautical industry and assesses airlines' strategies and targets. The research also aims to quantify the impact on the environment of domestic flights performed by two national airlines (i.e. Tarom and Blue Air) on a peak period in terms of air traffic, with accent on the emissions of $\mathrm{CO}$ and $\mathrm{CO}_{2}$ (which represents a linear function of fuel burn).
\end{abstract}

Keywords: air quality, emissions, environmental protection, Romanian national airlines

The air quality over the European continent has meliorated notably in the latest decades and nowadays, the European air quality values mainly show good to moderate index levels based on pollutant concentrations, over most of the countries [1,2]. On a large scale, this goal was achieved due to the implementation of mitigation measures and the commitment to sustainability.

Whilst aviation contributes with a marginal rate to global atmospheric concentrations, it has adopted a set of highaimed targets knowing that it can potentially produce forthcoming impacts. International aviation action plans, the implementation of specific regulations, technological and design improvements, and the transition to sustainable developmentrepresent important drivers to decreasing the environmental impact per flights. In recent years, without compromising on safety and having cost efficiency targets in mind, a better flight management and limiting engine emissions through technology were considered the best approach to reducing pollutants from air transport [3, 12].

In this context, determining the quality of the air in the vicinity of Romanian airports and the concentration of pollutants from the air space corresponding to the flight paths described by domestic flights during an imposed period, will be analyzed in comparison to national/ international regulations; thus indicating the levels of local air quality.

Gaseous emissions tests must be performed on engines which have reached a constant operating temperature [7]. The report will include certification data for $\mathrm{HC}_{1} \mathrm{NO}_{x}, \mathrm{SO}_{2}$, but mainly for $\mathrm{CO}$ and $\mathrm{CO}_{2}$, although in aviation carbon dioxide is not deemed as a regulated engine emission. Since $\mathrm{CO}_{2}$ emissions are particularly a global concern given its importance to climate change [4], local $\mathrm{CO}_{2}$ inventory development is useful for check purposes and can be used for global calculation where required [9].

Certificating authorities may recommend and provide guidance for the analytical techniques used to evaluate the concentrations of different gaseous emissions, but they may also accept alternative methods which provide accurate results. The indexes for various gaseous emissions will be calculated as follows:

$$
E I_{p}=\frac{\text { mass of } p \text { produced (in } g)}{\text { mass of fuel used (in } \mathrm{kg})}
$$

\section{Experimental part}

Air quality assessment reflected by airport-related and in-flight emissions represents the basis for calculating the impact on the environment of two Romanian national airlines, operating domestic flights. In the EU, local air quality regulations are expressed by the Air Quality Framework Directive, and the pollutant indicators are calculated (in $\mu \mathrm{g} / \mathrm{m}^{3}$ ) on an averaging period of $1 / 8 / 24 \mathrm{~h}$ or annually [9].

Table 1

LOCAL AIR QUALITY REGULATIONS FOR CO IN EU [9]

\begin{tabular}{|c|l|c|}
\hline \multirow{2}{*}{$\begin{array}{c}\text { Country/ } \\
\text { Organization }\end{array}$} & \multirow{2}{*}{$\begin{array}{c}\text { Pollutant } \\
\text { (averaging period) }\end{array}$} & $\mathrm{CO}$ \\
\cline { 3 - 3 } & & $\mathrm{Mg} / \mathrm{m}^{3}$ \\
\hline $\mathrm{EU}$ & $\begin{array}{l}\text { Air Quality Framework } \\
\text { Directive }\end{array}$ & 10 \\
\hline
\end{tabular}

For the measurements of $\mathrm{CO}$ and $\mathrm{CO}_{2}$ concentrations, non-dispersive infrared analyzers are used, and each test must comprise a verification that the air/fuel ratio is in accordance with the engine air/fuel ratio appraisal within $\pm 15 \%$ for the taxi mode, and within $\pm 10 \%$ for all other modes: including takeoff, climb, descent and approach [6].

$$
E I(\mathrm{CO})=\left(\frac{[\mathrm{CO}]}{\left[\mathrm{CO}_{2}\right]+[\mathrm{CO}]+[\mathrm{HC}]}\right)\left(\frac{10^{3} \mathrm{M}_{\mathrm{CO}}}{M_{\mathrm{C}}+(n / m) M_{H}}\right)\left(1+T\left(P_{O} / m\right)\right)
$$

The equation considers the mean concentrations of $\mathrm{CO}$ $\mathrm{vol} / \mathrm{vol}$, wet-[CO], of $\mathrm{CO}$ vol/vol, wet-[ $\left.\mathrm{CO}_{2}\right]$ and of exhaust hydrocarbons vol/vol, (expressed as carbon)-[HC], the molecular mass of (equal to $28.011 \mathrm{~g}$ ) $-\mathrm{M}_{C^{\prime}}$ the atomic mass of carbon (equal to $12.011 \mathrm{~g}$ )-, the atomic mass of hydrogen (equal to $1.008 \mathrm{~g}$ ) $-\mathrm{M}_{H}$, the concentration of $\mathrm{CO}_{2}$ in dry air, by volume (equal to 0.0003 normally) $-T$, the number of $\mathrm{H}$ atoms (in characteristic fuel molecule)- $n$ and the number of $\mathrm{C}$ atoms (in characteristic fuel molecule)$m[6]$.

\footnotetext{
*email: casandra.pietreanu@yahoo.com
} 
Similarly, the emission indexes for, $\mathrm{CO}_{2}, \mathrm{HC}, \mathrm{NO}$ and $\mathrm{SO}_{2}$ are calculated, applying, when appropriate, corrections to deem the deviations from the reference atmospheric conditions. The corrections take into account the fuel/air ratio in the combustor, the inlet pressure and temperature, and other constants specific to the pollutant or the type of engine analyzed [6].

The report presents an evaluation of air quality degradation in nearby communities during a week time. The period chosen for the study represents the week (1824 December 2017) before Christmas, one of the busiest periods of the year in terms of the evolution of aircraft movements and the number of passengers.

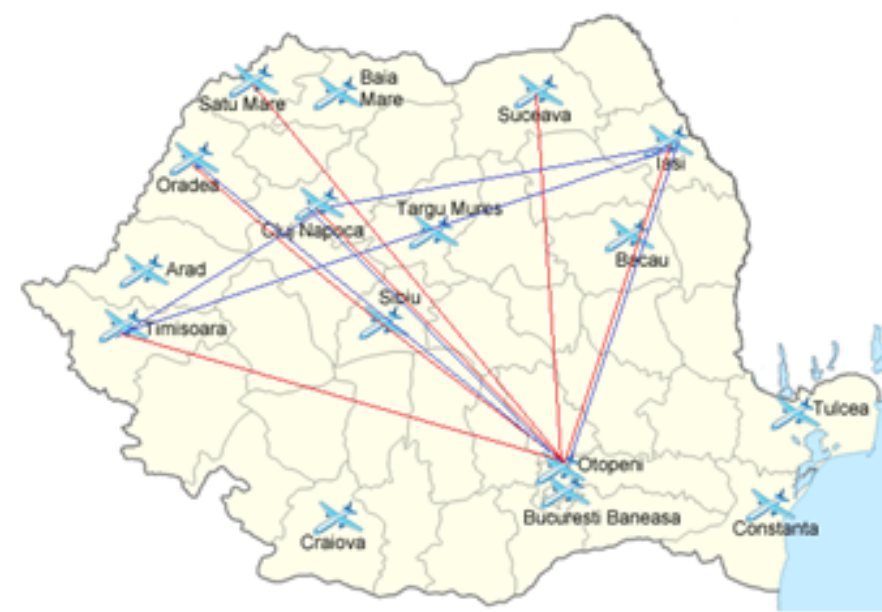

Fig.1 Studied area/domestic flights performed by Tarom (red line) and Blue Air (blue line)

The study regards 7 of the 16 existing Romanian airports, the ones on which the two national air carriers perform internal flights: Otopeni (OTP/LROP), Cluj (CLJ/LRCL), Iasi (IAS/LRIA), Oradea (OMR/LROD), Satu Mare (SUJ/LRSM), Suceava (SCV/LRSV), Timiooara (TSR/LRTL), as well as the air space above/connecting these airports. The research does not include sources of pollution other than aircraft emissions and airport activities; therefore it does not take into account emissions from surface access to airports. Also, the scoring metrics presented do not consider the noise envelope around the Romanian airports to which reference is made.
For developing a scoring metric regarding the impact of domestic flights on the environment, the authors could also calculate the $\mathrm{CO}_{2}$ emissions using data input from the two airlines analyzed. This regards the fleet of Tarom (RO/ROT) and Blue Air (OB/J OR), and it takes into account 7 different types of aircrafts: Airbus 318, Boeing 737-300/500/700/800, ATR 42-500 and ATR 72-500. The computations consider different parameters related to aircraft design and technology, such as: aircraft size, weight and fuel burn performance [11, 12]. This will be a focus point for bringing forward airlines' solutions and strategies as lever for meliorating air quality.

\section{Results and discussions}

For local and regional air quality assessment, the engine emissions data and the fuel flow rates were envisaged in the LTO cycles for takeoff, climb, descent, approach and taxi modes in accordance with Tarom and Blue Air's type of equipment used in the analyzed week.

The authors' approach on emission indexes calculations on the week analyzed eliminated the contaminants from the substances used in ADF and AAF fluids from de-icing/ anti-icing procedures, since conditions ranging from snow, heavy or consistent snow, ice or overcooled rains were not present in the period considered; thus airport procedures did not involve any extreme weather operations.

The total number of domestic flights performed by the two Romanian national airlines (Tarom and Blue Air) during a busy week (i.e. 18-24 th of December 2017) is 286. The flight scenario is valid for the mentioned period, as the number of flights differs from other periods of the year (i.e. is higher due to the holiday period). Other reasons may include Blue Air's decision to cancel operations on various routes such as Timisoara-Cluj-lasi. However, the two airlines' destinations in the period analyzed has the following aspect (fig.2).

Since the greatest part of the pollutants are discharged under $3000 \mathrm{ft}$, the impact on the environment of analyzed flights and airport contaminants (including APU operations for the 7 types of aircrafts) are reflected in the air quality, modified by the effects of LTO cycles [10]. The duration of APU operation involves the production of different amount of pollutants, depending on the type of equipment involved in the process; including 25/40 g of PM (particular matter) [8]. Since all the aircrafts provided by the two Romanian

\begin{tabular}{|l|c|c|c|c|c|c|}
\hline \multirow{2}{*}{ Aircraft } & \multicolumn{5}{|c|}{ LTO emission factors/aircraft $\mathrm{kg} / \mathrm{LTO} /$ aircraft } & \multirow{2}{*}{$\begin{array}{c}\text { Fuel consumption } \\
\text { (kg/LTO/aircraft) }\end{array}$} \\
\cline { 2 - 6 } & $\mathrm{CO}_{2}$ & $\mathrm{HC}$ & $\mathrm{NO}_{x}$ & $\mathrm{CO}$ & $\mathrm{SO}_{2}$ & \\
\hline Airbus 318 & 2310 & 0.59 & 8.73 & 6.35 & 0.73 & 730 \\
\hline Boeing 737-300/500 & 2480 & 0.84 & 719 & 13.03 & 0.78 & 780 \\
\hline Boeing 737-700 & 2460 & 0.86 & 9.12 & 8.00 & 0.78 & 780 \\
\hline ATR 42/72 & 620 & 0.29 & 1.82 & 2.33 & 0.20 & 200 \\
\hline
\end{tabular}

Table 2

LANDING AND TAKE-OFF EMISSION FACTORS PER AIRCRAFT TYPE [9]

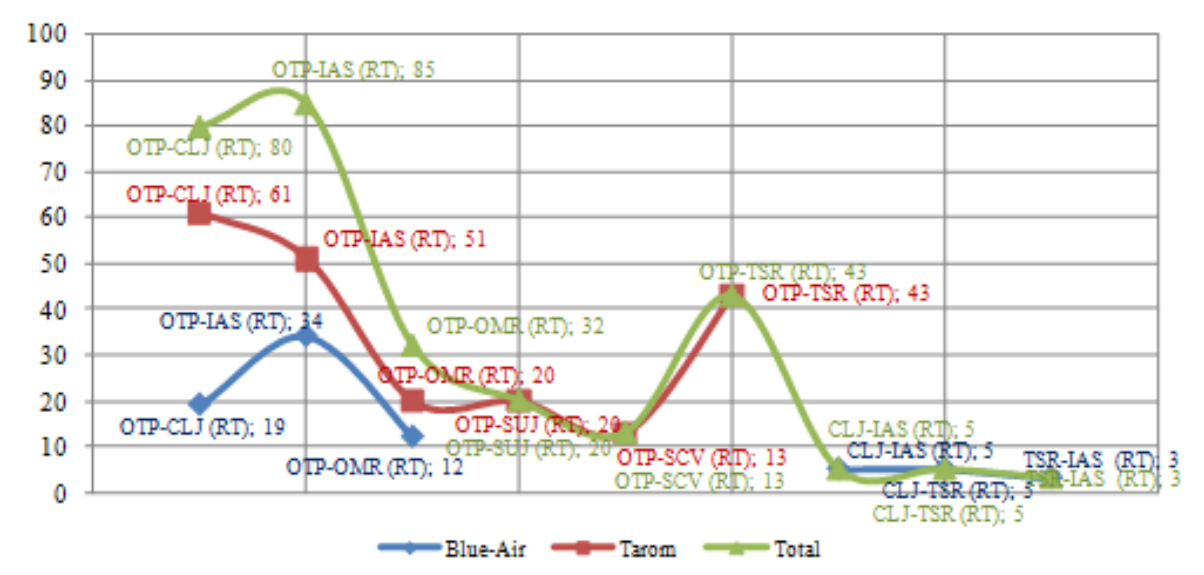

Fig. 2. Tarom and Blue Air flights/ destination/period analyzed 


\begin{tabular}{|c|c|c|c|c|c|c|}
\hline & Leg & $\begin{array}{l}\text { Tarom } \\
\text { flights }\end{array}$ & Flights/Type of aircraft & $\begin{array}{l}\text { Blue Air } \\
\text { flights }\end{array}$ & Flights/Type of aircraft & \\
\hline 1 & OTP-CLJ & 30 & $\begin{array}{l}\text { ATR 42-500 (19), ATR 72-500( } \\
\text { 6), Boeing } 737-700(5)\end{array}$ & 9 & Boeing 737-800(9) & \\
\hline 2 & CLJ-OTP & 31 & $\begin{array}{l}\text { ATR 42-500 (19), ATR 72-500 } \\
\text { (7), Boeing 737-700 (5) }\end{array}$ & 10 & Boeing 737-800(10) & \\
\hline 3 & OTP-IAS & 25 & $\begin{array}{l}\text { ATR 42-500(5), ATR 72-500 } \\
(19), \text { Boeing } 737-300 \text { (1) }\end{array}$ & 17 & Boeing $737-500(17)$ & \\
\hline 4 & IAS-OTP & 26 & $\begin{array}{c}\text { ATR 42-500(5), ATR 72-500 } \\
\text { (13), Boeing } 737-700(7) \text {, Airbus } \\
318 \text { (1) }\end{array}$ & 17 & Boeing 737-500(17) & Table 3 \\
\hline 5 & OTP-OMR & 10 & ATR $42-500(10)$ & 6 & Boeing 737-800 (6) & TAROM AND BLUE AIR FLIGHTS \\
\hline 6 & OMR-OTP & 10 & ATR 42-500 (10) & 6 & Boeing 737-800 (6) & PER WEEK (18-24 DECEMBER \\
\hline 7 & OTP-SUI & 10 & ATR $42-500(10)$ & - & - & \\
\hline 8 & SUJ-OTP & 10 & ATR $42-500(10)$ & - & - & \\
\hline 9 & OTP-SCV & 6 & ATR 42-500 (6) & - & - & \\
\hline 10 & SCV-OTP & 7 & ATR 42-500(7) & - & - & \\
\hline 11 & OTP-TSR & 21 & $\begin{array}{c}\text { ATR 42-500 (10), ATR 72-500 } \\
\text { (11) }\end{array}$ & - & - & \\
\hline 12 & TSR-OTP & 22 & $\begin{array}{c}\text { ATR 42-500 (11), ATR 72-500 } \\
\text { (11) }\end{array}$ & - & - & \\
\hline 13 & CLJ-IAS & - & - & 2 & Boeing 737-500/800(2) & \\
\hline 14 & IAS-CLJ & - & - & 3 & Boeing 737-500/800(3) & \\
\hline 15 & CLJ-TSR & - & - & 3 & Boeing 737-500(3) & \\
\hline 16 & TSR-CLJ & - & - & 2 & Boeing 737-500(2) & \\
\hline 17 & TSR-IAS & - & - & 2 & Boeing 737-500(2) & \\
\hline 18 & IAS-TSR & - & - & 1 & Boeing 737-500(1) & \\
\hline
\end{tabular}

air carriers are short-haul, the emissions for one operation, are as follows:

Table 4

VALUES FOR APU EMISSIONS PER AIRCRAFT OPERATION [9]

\begin{tabular}{|c|c|c|c|c|}
\hline $\begin{array}{c}\text { Aircraft } \\
\text { group }\end{array}$ & $\begin{array}{c}\text { Fuel } \\
\text { burn }\end{array}$ & $\begin{array}{c}\text { CO } \\
\text { emissions }\end{array}$ & $\begin{array}{c}H C \\
\text { emissions }\end{array}$ & $\begin{array}{c}N O_{x} \\
\text { emissions }\end{array}$ \\
\hline Short-haul & $80 \mathrm{~kg}$ & $310 \mathrm{~g}$ & $30 \mathrm{~g}$ & $700 \mathrm{~g}$ \\
\hline
\end{tabular}

For the 286 flights corresponding to the scenario outlined by the two airlines, the APU operations involve $22880 \mathrm{~kg}$ of fuel burn, $88660 \mathrm{~g}$ of CO emissions, $8580 \mathrm{~g}$ of $\mathrm{HC}$ and $200200 \mathrm{~g}$ of NO

Data provided by the national airlines involved in the study indicate that Tarom's average load factor (LF) for domestic flights in 2017 was $66 \%$ [13, 15], thus the authors could calculate the total aircraft fuel burn/journey and the emission index in kilograms for the $\mathrm{CO}_{2}$ gaseous pollutant. For the same period, the computations will be performed considering Blue Air's flight schedule, with its load factor $L F=69.77 \%[14,16]$.

\begin{tabular}{|c|c|c|c|c|c|c|c|}
\hline $\begin{array}{l}\text { Considered } \\
\text { leg }\end{array}$ & $\begin{array}{l}\text { Distance } \\
(\mathrm{km})\end{array}$ & $\begin{array}{l}\text { Equipment } \\
\text { (Type of } \\
\text { aircraft) }\end{array}$ & $\begin{array}{l}\text { No. of } \\
\text { flights } \\
\text { per } \\
\text { aircraft }\end{array}$ & $\begin{array}{c}\text { Pax } \\
\text { carrying } \\
\text { capacity }\end{array}$ & $\begin{array}{l}\text { No. of } \\
\text { revenue } \\
\text { paying } \\
\text { pax }\end{array}$ & $\begin{array}{l}\text { Total pax } \\
\text { per aircraft } \\
\text { type }\end{array}$ & $\begin{array}{c}\text { Total } \\
\text { pax per } \\
\text { legs }\end{array}$ \\
\hline \multirow{4}{*}{$\begin{array}{l}\text { OTP_CLJ/ } \\
\mathrm{CLJ} / \mathrm{OTP}\end{array}$} & \multirow{4}{*}{309} & $\begin{array}{c}\text { ATR 42- } \\
500\end{array}$ & 38 & 48 & 32 & 1216 & \multirow{4}{*}{5269} \\
\hline & & $\begin{array}{c}\text { ATR 72- } \\
500\end{array}$ & 13 & 68 & 45 & 585 & \\
\hline & & $\begin{array}{l}\text { Boeing } \\
737-700\end{array}$ & 10 & 146 & 96 & 960 & \\
\hline & & $\begin{array}{l}\text { Boeing } \\
737-800\end{array}$ & 19 & 189 & 132 & 2508 & \\
\hline \multirow{6}{*}{$\begin{array}{l}\text { OTP-IAS/ } \\
\text { IAS-OTP }\end{array}$} & \multirow{6}{*}{311} & $\begin{array}{c}\text { ATR 42- } \\
500\end{array}$ & 10 & 48 & 32 & 320 & \multirow{6}{*}{5723} \\
\hline & & $\begin{array}{c}\text { ATR 72- } \\
500\end{array}$ & 32 & 68 & 45 & 1440 & \\
\hline & & $\begin{array}{l}\text { Boeing } \\
737-300\end{array}$ & 1 & 134 & 88 & 88 & \\
\hline & & $\begin{array}{l}\text { Boeing } \\
737-700\end{array}$ & 7 & 146 & 96 & 672 & \\
\hline & & Airbus 318 & 1 & 113 & 75 & 75 & \\
\hline & & $\begin{array}{l}\text { Boeing } \\
737-500\end{array}$ & 34 & 132 & 92 & 3128 & \\
\hline \multirow{2}{*}{$\begin{array}{l}\text { OTP-OMR/ } \\
\text { OMR-OTP }\end{array}$} & \multirow[t]{2}{*}{423} & $\begin{array}{c}\text { ATR 42- } \\
500\end{array}$ & 20 & 48 & 32 & 640 & \multirow[t]{2}{*}{2224} \\
\hline & & $\begin{array}{l}\text { Boeing } \\
737-800\end{array}$ & 12 & 189 & 132 & 1584 & \\
\hline $\begin{array}{l}\text { OTP-SUJ/ } \\
\text { SUJ_OTP }\end{array}$ & 426 & $\begin{array}{c}\text { ATR 42- } \\
500\end{array}$ & 20 & 48 & 32 & 640 & 640 \\
\hline $\begin{array}{l}\text { OTP-SCV/ } \\
\text { SCV/OTP }\end{array}$ & 346 & $\begin{array}{c}\text { ATR 42- } \\
500\end{array}$ & 13 & 48 & 32 & 416 & 416 \\
\hline \multirow{2}{*}{$\begin{array}{l}\text { OTP-TSR } \\
\text { TSR/OTP }\end{array}$} & \multirow[t]{2}{*}{398} & $\begin{array}{c}\text { ATR 42- } \\
500\end{array}$ & 21 & 48 & 32 & 672 & \multirow[t]{2}{*}{1662} \\
\hline & & $\begin{array}{c}\text { ATR 72- } \\
500\end{array}$ & 22 & 68 & 45 & 990 & \\
\hline
\end{tabular}

Table 5

CHARACTERISTICS OF FLIGHTS PER WEEK

(18-24 DECEMBER 2017) 


\begin{tabular}{|c|c|c|c|c|c|c|c|}
\hline \multirow{2}{*}{$\begin{array}{c}\text { CLJ-IAS/ } \\
\text { IAS-CLJ }\end{array}$} & \multirow{2}{*}{301} & $\begin{array}{c}\text { Boeing } \\
737-500\end{array}$ & 3 & 132 & 92 & 276 & \multirow{2}{*}{540} \\
\cline { 3 - 7 } & & $\begin{array}{c}\text { Boeing } \\
737-800\end{array}$ & 2 & 189 & 132 & 264 & \\
\hline $\begin{array}{c}\text { CLJ-TSR/ } \\
\text { TSR-CLJ }\end{array}$ & 211 & $\begin{array}{c}\text { Boeing } \\
737-500\end{array}$ & 5 & 132 & 92 & 460 & 460 \\
\hline $\begin{array}{c}\text { TSR-IAS/ } \\
\text { IAS-TSR }\end{array}$ & 504 & $\begin{array}{c}\text { Boeing } \\
737-500\end{array}$ & 3 & 132 & 92 & 276 & 276 \\
\hline
\end{tabular}

Table 5

CONTINUATED
Aircraft fuel burn/jownsy $=\sum$ Arrcraft fuel burn/leg

Total passengers' $\mathrm{CO}_{2} /$ jowney $=$

$=\sum$ Passenger $\mathrm{CO}_{2} / \mathrm{pax} /$ leg $\cdot$ Number of $\mathrm{pax}$ (4)

Taking into consideration the distance between the proposed destinations, the type of aircraft used, and measures of traffic (available seat km-ASK and revenue passenger per km-RPK), the final indicators for fuel burn were provided.

Aircrafts' fuel burn $=A / c F b / O T P-C L J$ legs + $+A / c F b / O T P-L A S$ legs $+A / c F b / O T P-O M R$ legs + $+A / c F b / O T P-S U J$ legs $+A / c F b / O T P-S C V$ legs + $+A / c F b / O T P-T S R$ legs $+A / c F b / C L J-L A S$ legs + $+A / c F b / C L J-T S R$ legs $+A / c F b / T S R-L A S$ legs $=$ $=(80 \cdot 1916.8+85 \cdot 1311.8+32 \cdot 1406.0+20 \cdot 795.1+$ $+13 \cdot 699.5+43 \cdot 2157.2+5 \cdot 2233.4+5 \cdot 1735.1+3 \cdot 2944.9) \quad \mathrm{kg}$

Total aircrafts' fuel burn $=456271.3 \mathrm{~kg}$

The computations for the 8 legs analyzed take into account the equipment used by the airlines (i.e. if it used a winglet system, or applies a continuous descent approach procedure). In the case of Tarom, the second procedure is meant to reduce fuel consumption and $\mathrm{CO}_{2}$ emissions and involves the Airbus A318 aircrafts, since its objectives include obtaining an efficient fuel consumption of 1.5-2\% and achieving carbon neutrality by 2020 [13].

Regarding the average $\mathrm{CO}_{2}$ emissions/passenger, the single engine taxi procedure is used for both ATR 42/72500 and for the Airbus 318-111 [13] (used in the analyzed case only for the IAS-OTP leg) and has proved to be a good tool for reducing emissions by a 0.4 percent.

Total $\mathrm{CO}_{2} /$ pax $/$ legs $=\mathrm{CO}_{2} /$ pax $/(\mathrm{OTP}-\mathrm{CLJ})$ legs + $+\mathrm{CO}_{2} / \mathrm{pax} /(\mathrm{OTP}-\mathrm{IAS})$ legs $+\mathrm{CO}_{2} / \mathrm{pax} /(\mathrm{OTP}-\mathrm{OMR})$ legs + $+\mathrm{CO}_{2} / \mathrm{pax} /(\mathrm{OTP}-\mathrm{SUJ})$ legs $+\mathrm{CO}_{2} / \mathrm{pax} /(\mathrm{OTP}-\mathrm{SCV})$ legs + $+\mathrm{CO}_{2} / \mathrm{pax} /(\mathrm{OTP}-\mathrm{TSR})$ legs $+\mathrm{CO}_{2} / \mathrm{pax} /(\mathrm{CLJ}-\mathrm{IAS})$ legs + $+\mathrm{CO}_{2} / \mathrm{pax} /(\mathrm{CLJ}-\mathrm{TSR})$ legs $+\mathrm{CO}_{2} / \mathrm{pax} /(\mathrm{TSR}-\mathrm{IAS})$ legs $=$ $=80 \cdot 47.8 \cdot 5269+85 \cdot 42.7 \cdot 5723+32 \cdot 44.6 \cdot 2224+$ $+20 \cdot 40.4 \cdot 640+13 \cdot 35 \cdot 5 \cdot 416+43 \cdot 53 \cdot 0 \cdot 1662+$ $+5 \cdot 62.2 \cdot 540+5 \cdot 49.8 \cdot 460+3 \cdot 84.5 \cdot 276$
Total passengers' $\mathrm{CO}_{2}=48943625.3 \mathrm{~kg}$ (8)

The assessment of carbon dioxide emissions reflects the concentration of $\mathrm{CO}_{2}$ /leg in the exhaust samples, multiplied by the total number of passengers on each leg (i.e. 5269 on OTP-CL) and CLI/OTP, 5723 on OTP-IAS and IAS-OTP, 2224 on OTP-OMR/ OMR-OTP, 640 on OTP-SU]/ SUJ -OTP, 416 OTP-SCV RT, 1662 on OTP-TSR RT, 540 on CLJ -IAS and IAS-CLJ, 460 on CLJ-TSR and TSR-CLJ , 276 on TSR-IAS and IAS-TSR; total 17210 pax) transported in the analyzed week (18-24 December 2017). The calculations took into account the total number of passengers transported, not the airlines' flight passenger carrying capacity.

In the light of the above mentioned directives, the implementation of a responsibility policy for all actors in aviation is meant to incentivize continuous improvement of environment protection measures for achieving compliance with international regulations. Blue Air's fleet consists of 28 Boeing 737 aircraft series (i.e. two 737-300, six 737-400, six737-500, one 737-700, thirteen 737800 ) and states that the fleet selection mirrors the yearning and demand to reduce fuel consumption and to lower emissions [14]. Tarom's environmental responsibility program includes 3 major initiatives: Continuous Descent Approach procedure, Single Engine Taxi procedure and the use of Winglet System.

A forecast performed by the Council of Aerospace Industries Associations shows that new technologies will amend fuel burn by $1.6 \%-2.5 \%$ per year and will improve fuel efficiency from 5 liters (in 2005) to 3 liters/pax/100 $\mathrm{km}$ by 2025 [5].

National airlines will also have to implement solutions relative to the capabilities of their aircrafts for obtaining an even greater reduction of fuel/oil and emissions, in order to match one of the International Civil Aviation Organization's technology improvement related scenarios regarding the 2050 target for climate change solution.

Already, a $3 \%$ reduction on emissions and fuel consumption is achieved through the winglets installed on Tarom's Boeing 737-700 aircrafts, and for the Airbus 318, the continuous descend approach involves a reduction of $350 \mathrm{~kg} \mathrm{CO}_{2}$ on every flight [13].

\begin{tabular}{|c|c|c|c|c|c|c|c|c|c|c|c|}
\hline Considered leg & $\begin{array}{l}\text { OTP- } \\
\text { CLJ }\end{array}$ & $\begin{array}{l}\text { OTP- } \\
\text { IAS }\end{array}$ & $\begin{array}{l}\text { OTP- } \\
\text { OMR }\end{array}$ & $\begin{array}{l}\text { OTP- } \\
\text { SUJ }\end{array}$ & $\begin{array}{l}\text { OTP- } \\
\text { SCV }\end{array}$ & $\begin{array}{l}\text { OTP- } \\
\text { TSR }\end{array}$ & $\begin{array}{l}\text { CLJ- } \\
\text { IAS }\end{array}$ & \multicolumn{2}{|r|}{$\begin{array}{l}\text { CLJ- } \\
\text { TSR }\end{array}$} & $\begin{array}{l}\text { TSR- } \\
\text { IAS }\end{array}$ & \multirow{2}{*}{$\begin{array}{c}\text { Table } 6 \\
\text { CALCULATED } \\
\text { AIRCROFT FUEL BURN } \\
\text { PER LEG }\end{array}$} \\
\hline $\begin{array}{l}\text { Aircraft Fuel } \\
\text { Bum/leg (kg) }\end{array}$ & 1916.8 & 1311.8 & 1406.0 & 795.1 & 699.5 & 2157.2 & 2244 & \multicolumn{2}{|r|}{1735.1} & 2944.9 & \\
\hline Considered leg & $\begin{array}{l}\text { OTP- } \\
\text { CLJ }\end{array}$ & $\begin{array}{l}\text { OTP- } \\
\text { IAS }\end{array}$ & $\begin{array}{l}\text { OTP- } \\
\text { OMR }\end{array}$ & $\begin{array}{l}\text { OTP- } \\
\text { SUJ }\end{array}$ & $\begin{array}{l}\text { OTP- } \\
\text { SCV }\end{array}$ & $\begin{array}{l}\text { OTP- } \\
\text { TSR }\end{array}$ & $\begin{array}{l}\text { CLJ- } \\
\text { IAS }\end{array}$ & $\begin{array}{l}\text { CLJ- } \\
\text { TSR }\end{array}$ & $\begin{array}{l}\text { TSR- } \\
\text { IAS }\end{array}$ & & Table 7 \\
\hline $\begin{array}{c}\text { Passenger } \mathrm{CO}_{2} / \text { pax } \\
\text { leg }(\mathrm{kg})\end{array}$ & 47.8 & 42.7 & 44.6 & 40.4 & 35.5 & 53.0 & 62.2 & 49.8 & 84.5 & & \\
\hline
\end{tabular}

\begin{tabular}{|l|l|l|l|}
\hline Scenario & \multicolumn{1}{|c|}{ Name } & \multicolumn{1}{|c|}{$\begin{array}{c}\text { Technology } \\
\text { improvement }\end{array}$} & Period \\
\hline 1 & $\begin{array}{l}\text { Low aircraft technology + moderate operational } \\
\text { improvement }\end{array}$ & $0.76 \%$ year & $2010-2050$ \\
\hline 2 & Moderate aircraft technology + operational improvement & $0.96 \%$ year & $2010-2050$ \\
\hline 3 & Advanced aircraft technology + operational improvement & $1.16 \%$ year & $2010-2050$ \\
\hline 4 & $\begin{array}{l}\text { Optimistic aircraft technology + advanced operational } \\
\text { improvement }\end{array}$ & $1.50 \% /$ year & $2010-2050$ \\
\hline
\end{tabular}

Table 8

TECHNOLOGY IMPROVEMENT RELATED SCENARIOS FOR FUEL BURN AND [10] 


\section{Conclusions}

The report presents the evaluation of Romanian air carriers Tarom and Blue Air's contribution to air trafficrelated pollution, showing acceptable levels of local air quality.

The paper included the airlines' measures applied in order to achieve values of the concentrations of gaseous emissions within the limits imposed by standards and regulations, expressed for example by the Air Quality Framework Directive. The research has focused on the emissions of carbon dioxide, the largest driver of climate change, which was analyzed as a linear function of fuel burn. Taking into account different parameters related to aircraft characteristics: size, weight and fuel burn performance, but also regarding traffic indicators mirrored by the number of revenue paying passengers, the computations were performed for total $\mathrm{CO}_{2}$ emissions.

In this concern, the authors consider that the two air carriers should focus on bringing forward solutions especially regarding carbon trading-as a key lever of responsibility policy improvement.

\section{References}

1. BRUYNINCKX H., Cleaner air benefits human health and climate change, European Environment Agency, Issue 2017/4, December 2017, p. 3

2. BRUYNINCKX H., Towards global sustainability, European Environment Agency, Issue no. 2015/3, September 2015, p. 2

3. CAREY C., Future of mobility roadmap, Chapter 3, Air, Oxford University, Smith School of Enterprise and the Environment, 2010, p. 4
4. FABER J., GREENWOOD D., LEE D., MANN M., MENDES DE LEON P., NELISSEN D., OWEN B., RALPH M., TILSTON J., VAN VELZEN A., VAN DE VREEDE G., Lower NOx at higher altitudes policies to reduce the climate impact of aviation NOx emission, CE Delft Solutions for environment, Economy and Technology, Delft, October 2008, pp. 1928

5. HIND P., RDC Aviation Ltd., The sustainability of UK Aviation: Trends in the mitigation of noise and emissions, Independent Transport Commission, March 2016, p. 9

6.***Annex 16 to the Convention on International Civil Aviation, Environmental Protection, Volume II, $3^{\text {rd }}$ edition: Aircraft Engine Emissions

7. ***FAA Fuel venting and exhaust emission requirements for turbine engine powered airplanes, Advisory Circular 34-1B, U.S. Department of Transportation, Federal Aviation Administration, FAA

8. ***Honeywell Engines \& Systems to U.S. EPA Assessment and Standards Division, APU Emissions, September, 2009

9. ***International Civil Aviation Organization, ICAO Doc 9889 Airport Air Quality Manual

10.***International Civil Aviation Organization, ICAO Environmental Report 2016, Aviation and climate change

11.*** International Civil Aviation Organization, ICAO Fact Sheet, AIRCRAFT emissions standard metric system, AN 1/17

12.***https://w w w.icao.int/environmental-protection/Pages/ default.aspx

13. ***https://www.tarom.ro

14. ***https://www.blueairweb.com

15. ***http://ww w.anna.aero/2016

16. ***http://www.talaviation.com/Blue-Air

Manuscript received: 7.05 .2018 